\title{
Heritability of Personality
}

\author{
Denis Bratko, Ana Butković, Tena Vukasović Hlupić \\ Department of Psychology, Faculty of Humanities and Social Sciences, \\ University of Zagreb, Croatia
}

\begin{abstract}
The aim of this study is to simplify the issue of the concept of heritability, to give an introduction to the behavioral genetic theory and methods, as well as to give an overview of the current knowledge about heritability of personality and the quantitative and molecular genetic approach to estimate heritability. Following that, results on heritability of personality are summarized. In addition, we reanalyzed all available behavioral genetic studies published before 2010, which were included in Vukasović and Bratko (2015) meta-analysis, to estimate the correlations between different family members: 1) monozygotic twins reared together; 2) monozygotic twins reared apart; 3) dizygotic twins reared together; 4) dizygotic twins reared apart; 5) mother and offspring; 6) father and offspring. Estimates of the family resemblance for personality were .54 from intraclass correlations for twin pairs reared together, .45 for intraclass correlations for monozygotic twin pairs reared apart, and .26 and .28 for familial aggregation. This finding is in line with the conclusion of the previous meta-analysis, which showed that the study design is a significant moderator of personality heritability, with twin studies showing higher estimates compared to family and adoption studies. Following that, findings from molecular genetic studies on personality and from gene-environment interaction studies are summarized. Finally, recommendations for future studies are given.
\end{abstract}

Keyword: heritability, personality, behavior genetics, meta-analysis

Personality is "One of the classical 'chapter heading' words in psychology. That is, a term so resistant to definition and so broad in usage that no coherent simple statement about it can be made ...", says a witty but truthful definition in the form of a dictionary entry (Reber, 1995, p. 555). One more serious, but equally truthful definition, says that personality can be conceptualised as: "the set of psychological traits and mechanisms within the individual that are organized and relatively enduring, and influence his or her interactions with, and adaptations to, the intrapsychic, physical, and social environments" (Larsen \& Buss, 2014, p. 4). Obviously, there are many personality definitions and a lot of personality theories as

Denis Bratko, Department of Psychology, Faculty of Humanities and Social Sciences, University of Zagreb, Ivana Lučića 3, 10000 Zagreb, Croatia. E-mail: dbratko@ffzg.hr 
well. The reason for that is simple - personality is a complex concept covering many behavioral (sometimes not only behavioral) phenomena. One of the most fundamental questions in personality psychology is related to its etiology. It is reasonable to assume that complex behavioral characteristics have complex etiology, or, in other words, that personality development and individual differences in personality characteristics are a consequence of a complex interplay between the genes and the environment, and between genetically or environmentally guided processes. Even if we approach personality only at the structural level (i.e. as a set of hierarchically organized traits), like some of the behavioral genetic studies do, there is still a lot of room for complexity and ambiguity. For example, in different personality theories, personality structure is organized so that the same or similar lower level concepts belong to different higher order personality concepts (named factors, dimensions, or domains). Sometimes 'factors', which have the same or similar name, actually have different content and, vice versa, sometimes the same content is hiding under a different label. This can introduce some ambiguity into the interpretation and the understanding of the behavioral genetic findings, which are essentially based on the covariation between measures of personality and genetic properties of individuals in a particular group or population. For example, the genetic effect on impulsivity would contribute to the genetic effect on extraversion if we used Eysenck's original, unrevised theory (Eysenck, 1967) operationalized in Eysenck Personality Inventory (EPI) as a measure of personality, or to neuroticism if we used Five-factor model operationalized into NEO-PI-R as a personality measure (Costa \& McCrae, 1992). Similarly, the genetic effect on shyness may reflect the genetic effect on extraversion and neuroticism since both extraversion (negatively) and neuroticism (positively) correlate with shyness. Complexity, although not always recognized, exists on the other, "genetic side" as well. Gene expression is a complex issue dependent on the different processes at the molecular level, but also on the environmental, and even cultural level (e.g. see Chiao \& Blizinsky, 2010). However, the aim of this article is not to add to the complexity. The aim is rather to simplify the issue and give an introduction to the behavioral genetic theory and methods, as well as to give an overview of the current knowledge about the heritability of personality.

\section{Concept of Heritability}

Heritability is a parameter of the population. It is not a property of any particular individual and, similar to the other population parameters like arithmetic mean or correlation, it can be used in order to describe the phenomena and its relations or effects at the population level. Technically, heritability could be defined as a proportion of the variability in some observable characteristic that is associated with the genetic variation in population (Plomin, DeFries, McClearn, \& McGuffin, 2008). If we apply this reasoning to the personality variations between individuals, then we can say that heritability of personality refers to the proportion of the variation in 
personality that is associated with the genetic variation between individuals within population. Therefore, in order to understand the concept of personality heritability, the key issue is to understand the concept of individual differences, which is statistically described with one additional population parameter - the variance.

\section{Variance: Phenotypic, Genetic and Environmental}

People are different. Some of them are tall, while others are short; some are generally healthy, while others are more prone to diseases in general or to some specific disease; some are stable, while others tend to overreact in stressful situations, etc. We can observe individual differences in a large number of observable dimensions. One of the fundamental questions that we want to answer is how to explain individual differences, or to what extent are these observable differences due to underlying genetic and environmental differences between individuals.

The characteristic of an individual, which we observe is called a phenotype. Phenotype is a broad term for any characteristic of an organism that can be observed and, therefore, measured and analyzed. However, in psychology we often study behavioral characteristics or, in other words, phenotypes that are expressed in behavior. Personality is also expressed in behavior and therefore personality traits can be considered as behavioral phenotypes. Behavior genetics, as a scientific field, is grounded on the idea that behavior, as a phenotype, can be analyzed with the same theories and methods as any other (i.e. anthropological or biological) phenotypes. Genetic characteristic of an organism is often labeled with the term genotype. Genotype is expressed in the phenotype. However, it is important to understand that, although a genotype may be fully expressed in a phenotype, it may also be expressed only partially or it may not be expressed at all. The gene penetration may differ for different genes, and is sometimes dependent on the very complex process regulated by the environment or other genes. Let us assume that someone possesses the genotype, which contributes to the development of depression as a reaction to stressful experiences. If those persons live in a stable and predictable environment, their genotype may never be expressed in their phenotype. However, in order to understand the concept of heritability, we must change our focus from the individual level to the level of individual differences in the population.

Behavior genetics is a scientific field focusing on identifying the genetic and the environmental sources of individual differences in behavioral phenotypes. In the case of personality, the goal is to understand individual differences in personality. Therefore, behavior genetic studies focus on the phenotypic variance of the trait of interest. We know that distributions of the behavioral phenotypes are usually continuous - so called bell curved, Gaussian, or normal distributions. The basic assumption of the behavioral genetic theory is that phenotypic variance in the population may be divided into the genetic and environmental variance, which may be combined linearly: $\mathrm{V}_{\mathrm{P}}=\mathrm{V}_{\mathrm{G}}+\mathrm{V}_{\mathrm{E}}$, where $\mathrm{V}_{\mathrm{P}}, \mathrm{V}_{\mathrm{G}}$, and $\mathrm{V}_{\mathrm{E}}$ represent phenotypic, 
genetic and environmental variance in the population, respectively (Plomin et al., 2008). Of course, theory allows for, and behavior genetic studies may focus on, some other types of interplay between genes and environment (e.g. genetic and environmental correlation or interaction), and even on the moderation of the heritability estimates by some third variable. The truth is that, although we usually measure phenotype very precisely, we actually do not have direct measures of the genetic and environmental variance in the population. For that reason the heritability estimates come from models in which we measure phenotypic similarity of the special groups of individuals, who share the genetic or environmental variation to the known degree. For example, we can use individuals who are more or less genetically similar, or individuals who shared or did not share the environment to which they were exposed during their development.

Individual genetic effects in the population may be combined in additive or nonadditive way. Additive genetic effect is a result of the linear combination of the individual genetic effects, while non-additive genetic effects include some form of non-linear combinations of the genetic effects, e.g. dominance, which is a combination of the genetic effects from genes that are located on the same locus on the chromosome, or epistatic interaction, which is a combination of the genetic effects of the genes that are located on the different locus (Plomin et al., 2008). Therefore, total genetic variance in the population can be divided into additive and non-additive parts: $\mathrm{V}_{\mathrm{G}}=\mathrm{V}_{\mathrm{GA}}+\mathrm{V}_{\mathrm{GNA}}$, where $\mathrm{V}_{\mathrm{G}}, \mathrm{V}_{\mathrm{GA}}$, and $\mathrm{V}_{\mathrm{GNA}}$ are hypothetical total genetic, additive genetic and non-additive genetic variance in the population, respectively. Since theory differentiates additive and non-additive genetic influences, we can also differentiate two concepts of heritability. Broad-sense heritability includes both additive and non-additive genetic sources of influence, while narrowsense heritability represents only additive genetic influences. These different types of heritability estimates are not only theoretically relevant, but are of practical interest as well. Only additive genetic effects will run in the family or, in other words, will be passed on from parents to their offspring, because offspring inherit individual genes from their parents. They do not inherit a package or a particular combination of genes. Therefore, although a non-additive genetic effect may contribute to the individual differences in both parents and offspring, it cannot be passed from one generation to another. The non-additive genetic effect may occur in each generation from the configuration of the individual genes as a result of probability laws. In the studies of plants or animal breading, only additive genetic effects are useful for selection of a desired characteristic of the species. However, in behavioral science, we do not use selection in that way and, from the behavioral genetic perspective, we can safely say that the broad-sense heritability is more important than the narrowsense heritability.

Environmental part of the phenotypic variance can also be divided into two parts: $V_{E}=V_{E S}+V_{E N S}$, where $V_{E}, V_{E S}$, and $V_{E N S}$ are hypothetical total environmental, shared environmental and non-shared environmental variance in the population, 
respectively (Plomin et al., 2008). The concepts of shared and non-shared environmental variance are derived from their effects on the individuals. Shared environmental influences contribute to the phenotypic similarity of individuals who are exposed to the same environment, while non-shared environmental influences represent unique influences, which do not contribute to the similarity of different family members. For example, if we consider only family environment, obviously the same specific environmental factor (e.g. parental affection or control), may be either shared or non-shared, dependent on its contribution to similarity or differences of the family members. Of course, sources of environmental influence may lie outside the family environment, e.g. in peer group influences (see Harris, 1998; Plomin \& Daniels, 1987).

\section{How to Estimate Heritability: The Quantitative and Molecular Genetic Approach}

Behavioral genetics as a field is comprised of two, although related and oriented to the same goal, quite distinctive methodological approaches. First approach includes quantitative behavioral methods, which are logically grounded on the examination of the genetically or environmentally informative groups of individuals. Second approach includes molecular genetic methods, which examine DNA directly and relate individual differences in DNA with individual differences in behavioral phenotypes.

The logic behind quantitative behavioral genetic methods is quite simple and includes few steps: (i) finding individuals who share genes or environment to a known degree; (ii) measuring their phenotypic similarity; (iii) searching for the model of the genetic and environmental influences consistent with the observed phenotypic similarity; and finally, (iv) estimating the degree of genetic and environmental influence. Although this idea has many variations, we can differentiate between three basic groups of quantitative behavioral genetic methods: twin studies, family studies, and adoption studies. Of course, various combinations are possible (and welcomed), so extended families, pedigree studies, twin/family or twin/adoption studies are very useful.

Classical twin study, which compares the similarity of identical and fraternal twins reared together, is the most popular behavioral genetic design. The idea is that identical twins are genetically identical, while fraternal twins, on average, share 50 percent of their genes, which means that the observed difference in their phenotypic similarity could be attributed to their genetic difference. Family and/or adoption study includes investigation of the similarity of different family members. For example, mothers and offspring who live together share 50 percent of their genes and 100 percent of shared environment contributing to their similarity, and therefore in this design the genetic and shared environmental influences are confounded. In another example, biological mother and adopted-away children share only 50 percent 
of their genes, while adoptive parents and their adoptees share 100 percent of family environment contributing to their similarity. Theoretically, these different study designs should converge to the same conclusion about the heritability and environmental influences on personality. Twin/family study combines both twin pairs and their family members (parents, siblings, children, spouses, etc.), which allows for simultaneous assessment of all possible genetic and environmental influences (Keller, Coventry, Heath, \& Martin, 2005). This study design was in part made possible by the development of modern statistical software and faster computers that can run more complex behavior genetic models. However, there is a potential problem with this study design as well - it requires extremely large data sets to simultaneously compute all parameters because the estimated effect sizes are very small. In other words, these type of studies are usually based on at least 10000 participants (Posthuma \& Boomsma, 2000).

Developments in biology and genetics throughout the $20^{\text {th }}$ century have led to the development of molecular genetics, a field that has rapidly advanced since 1970s (Nelson, Pettersson, \& Carlborg, 2013). Development of the new molecular genetic techniques has also led to new developments in quantitative genetic research, such as methods for QTL ${ }^{1}$ mapping and genomic prediction. Molecular genetic research is aimed at the genes or DNA, directly trying to associate differences in genes or DNA with differences in gene products (known as functional genomics) or with behavioral differences among people (known as behavioral genomics). Two main methods have been used - linkage studies and candidate gene association studies. Linkage studies use members of the same families to find if those members who share the same genetic marker, part of DNA that differs among people, also share the same characteristic (e.g. personality trait or, to be more precise, similar position along the quantitative distribution of the trait within a particular population). Candidate gene association studies investigate a statistical relationship between genes or genetic variants and the characteristic of interest, which means that members of the same families are not necessarily needed as subjects. In other words, the aim of the candidate gene association studies is to identify gene variants important for a characteristic of interest by comparing genetic variants between people with and without the characteristic of interest. The newest molecular genetic method used extensively is genome wide association study (GWAS). GWAS uses DNA microarrays (chips) containing probes for hundreds of thousands, or a million or more, single-nucleotide polymorphisms (SNPs) that tag common variation across the genome. SNP is a single unit of DNA that takes only two values across people. GWAS can detect even small genetic effects, but demands very large samples and stringent statistical thresholds to adjust for multiple testing.

\footnotetext{
${ }^{1}$ Term QTL is an acronym for the Quantitative Trait Loci which means Loci (or segment of DNA) that correlates with the quantitatively distributed trait as a phenotype.
} 


\section{Finally, the Heritability of Personality}

As stated earlier, personality is a very broad term and personality psychology is a field in which we can find very different theoretical approaches - for example psychoanalytical, humanistic, cognitive, or trait approach (e.g. see Cervone \& Pervin, 2016). Obviously, the most fruitful approach for behavior genetic studies of personality are those personality theories or models that use the concepts of individual differences, so called trait-theories.

The majority of behavioral genetic studies are conducted using the Big Five (extraversion, agreeableness, conscientiousness, emotional stability, and intellect; Goldberg, 1990) or the Five-Factor Model (extraversion, agreeableness, conscientiousness, neuroticism, and openness; Costa \& McCrae, 1992); Eysenck's PEN model (psychoticism, extraversion, and neuroticism; Eysenck, 1990); and Tellegen's model (positive affect, negative affect, and constraint; Tellegen, 1982). The reason is that all trait theories or models are operationalized with reliable and valid measures, which are normally distributed in the population. Thus, the straightforward approach for testing the genetic hypothesis is to relate these individual differences in personality traits with the genetic similarity within a population. All of these trait models include some form of extraversion and neuroticism factor, and we can safely claim that these two traits are the most often studied traits in the behavioral genetic literature.

Overall, the results of behavioral genetic studies converge on the conclusion that personality is substantially heritable, with the heritability estimate around .40 , meaning that $40 \%$ of individual differences are due to the genetic differences in the population (Krueger \& Johnson, 2008; Turkheimer, Pettersson, \& Horn, 2014; Vukasović \& Bratko, 2015). However, this is an average estimate. It seems that the study design has a significant moderation effect. Heritability estimates from twin studies are slightly below .50, while estimates from the family/adoption design are substantially lower, slightly above .20 (Vukasović \& Bratko, 2015). The reason for this inconsistency may lie in the importance of the non-additive genetic effect or gene to gene interactions, because family and adoption design estimate only the narrowsense heritability. However, it may also be due to some other effect related to the twin or family/adoption design. Environmental influences that contribute to the personality variability are almost exclusively non-shared between family members. Thus, family members are similar due to their shared genes - not due to their shared family environment (Plomin et al., 2008). However, biometrical estimates of nonshared environmental effect are much larger than the effect sizes typically found in the studies that use measures of non-shared environmental variables (Turkheimer \& Waldron, 2000). Fascinating finding is that all personality traits are heritable to the similar degree (Loehlin, 1978, 1982, 2012). Formal testing of the differential heritability hypothesis in a meta-analysis indicates that there is no evidence for that effect (Vukasović \& Bratko, 2015). Overall, research of familial resemblance on 
personality traits is very consistent. Correlations of identical twins always exceed the correlations of fraternal twins, and although very low, correlation of parents and offspring are always positive. It seems that quantitative genetic findings in personality domain follow the universal pattern which is observed for other behavioral traits, formulated in a form of behavioral genetic laws (Turkheimer, 2000, p. 160): 1) all behavioral traits are heritable; 2) the effect of family environment is smaller than the effect of genes; and 3) substantial portion of the variance is not accounted for by the effect of genes or family environment (see also Turkheimer \& Gottesman, 1991).

In order to estimate the familial resemblance for personality, we reanalyzed all available behavioral genetic studies published before 2010, which were included in Vukasović and Bratko (2015) meta-analysis (see Table 1). In that study the metaanalysis of heritability estimates was performed. Thus, the input effect sizes for the analysis in that study were independent heritability estimates from all of the available individual behavioral genetic studies. Here, we used the same population of studies to perform meta-analyses at the level of familial correlations. Thus, in this analysis the input data were familial correlations from the individual behavioral genetic studies. Thus, six separate meta-analyses were performed in order to estimate the correlations between: 1) monozygotic twins reared together; 2) monozygotic twins reared apart; 3) dizygotic twins reared together; 4) dizygotic twins reared apart; 5) mother and offspring; 6) father and offspring.

Estimates of the family resemblance for personality are presented in the Table 2. The intraclass correlations between family members in each individual study represent the effect sizes in these meta-analyses. We calculated two estimates for each effect size: (i) average correlation, and (ii) weighted average correlation, with 95\% confidence intervals. To report the weighted effect sizes, we conducted six separate meta-analyses. A detailed description of the meta-analytic process, including (but not limited to) literature search, inclusion/exclusion criteria, coding procedures, and data analysis, can be found elsewhere (see Vukasović \& Bratko, 2015). Here, we will only address the issue pertinent to understanding the data represented in Table 2. In order to parsimoniously reflect correlation coefficients from different study designs, we developed coding procedures with appropriate formulas for twin studies and family studies. In studies of twins reared together and apart, the procedure to calculate average intraclass correlations from each study included three steps, which were: (i) intraclass correlations for each personality trait were transformed into Fisher's $r_{\mathrm{Z}}$; (ii) an average $r_{\mathrm{Z}}$ for $\mathrm{MZ}$ and $\mathrm{DZ}$ twin pairs were calculated; and (iii) the average $r_{\mathrm{z}}$ for MZ and DZ twin pairs were transformed into intraclass correlations and coded as effect sizes. The same procedure was followed in order to calculate the average intraclass correlations represented in the first row of Table 2. However, this indicator might be biased because the average effect size, calculated in this manner, represents a simple linear combination of all primary studies' effect sizes. It does not take into account the fact that effect sizes from studies 
Bratko, D., Butković, A., Vukasović Hlupić, T.

Heritability of Personality

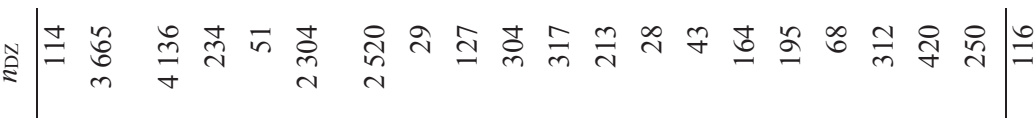

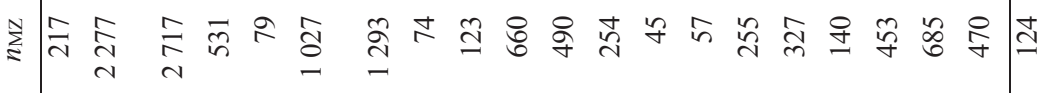

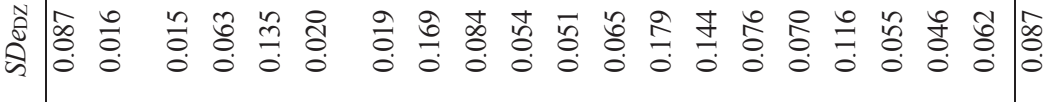

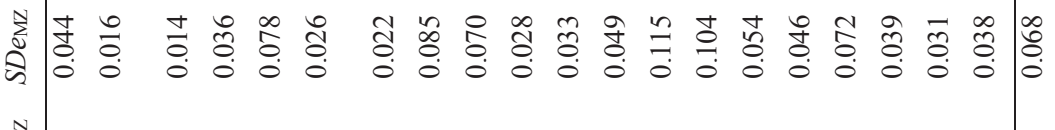

لِల్ల

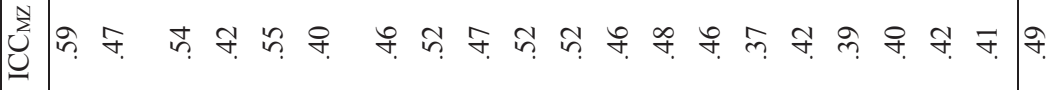

is

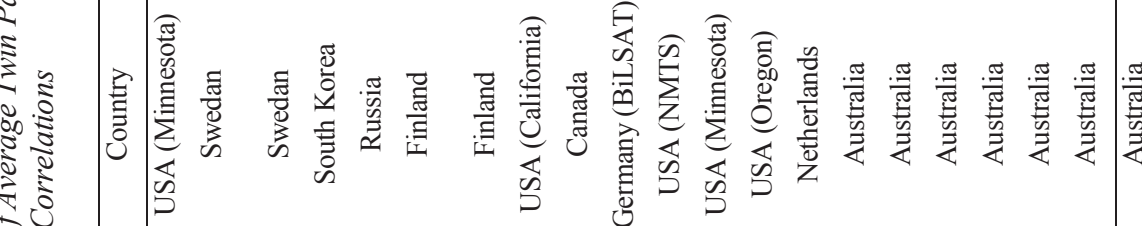

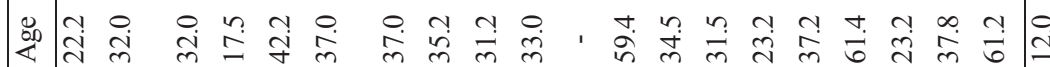

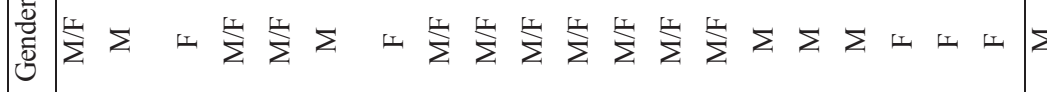

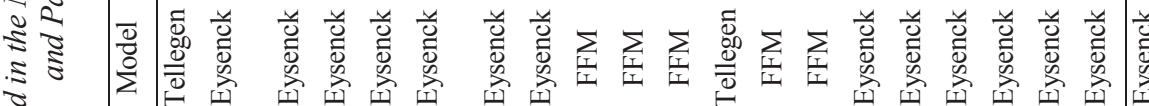

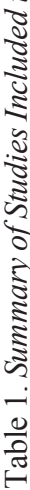

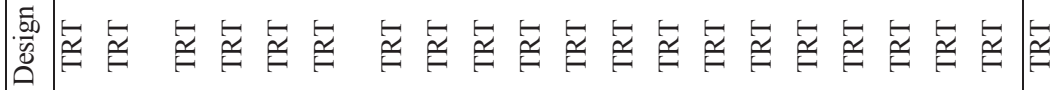




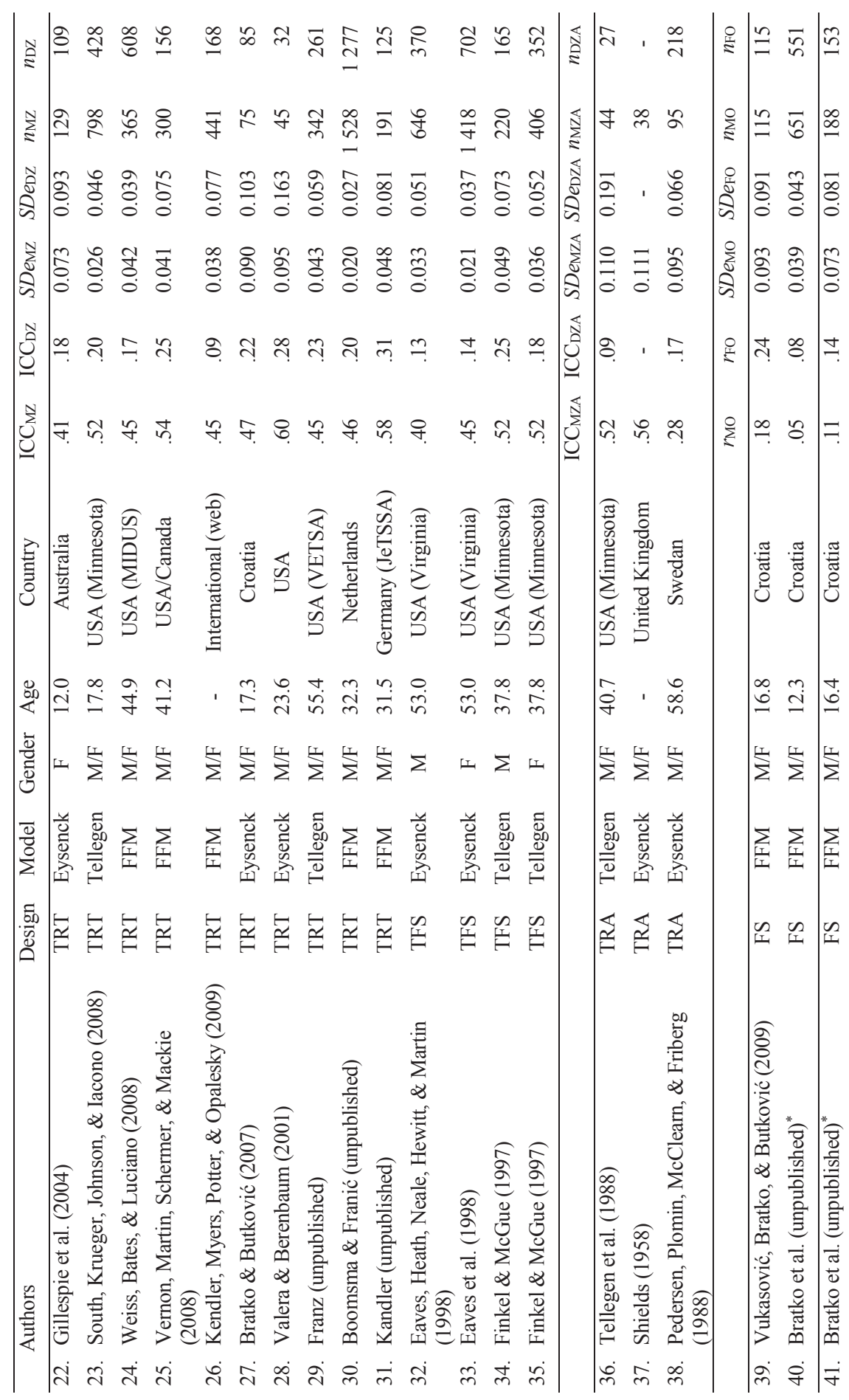




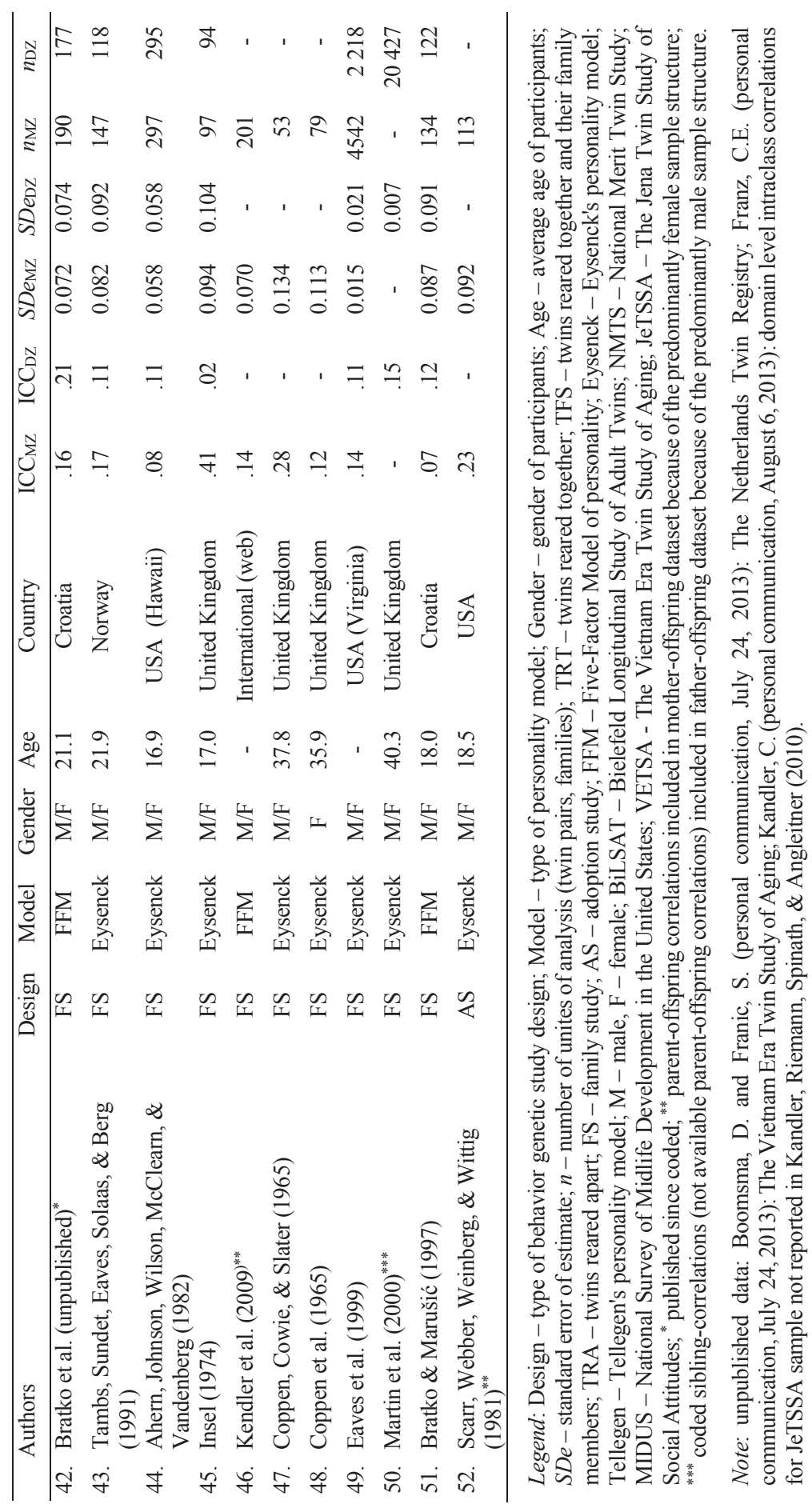


with larger sample sizes have smaller standard errors of estimate, and thus represent a more precise estimate - closer to the true effect size we aim to assess. In order to circumvent this potential bias, we decided to conduct six separate meta-analyses.

Eighty-five percent of all effect sizes included in the meta-analyses were triple coded by independent coders (the third author and two additional independent coders $^{2}$ ). Interrater agreement was calculated to insure the reliability of the coding process. Krippendorff's $\alpha$ (Hayes \& Krippendorff, 2007), an interrater reliability coefficient calculated for coding of effect sizes, was .98 indicated a very high level of coding reliability.

Table 2. Results of the Average and Meta-Analysed Intraclass Correlations for Twin Pairs ( $\left.r_{M Z I D Z}\right)$, Mother-Offspring $\left(r_{M O}\right)$, and Father-Offspring $\left(r_{F O}\right)$ Correlations

\begin{tabular}{lcccccc}
\hline & $r_{\mathrm{MZ}}$ & $r_{\mathrm{DZ}}$ & $r_{\mathrm{MZA}}$ & $r_{\mathrm{DZA}}$ & $r_{\mathrm{MO}}$ & $r_{\mathrm{FO}}$ \\
\hline Average effect size & .48 & .21 & .46 & .13 & .17 & .14 \\
\hline $\begin{array}{l}\text { Weighted effect size } \\
\text { (meta-analysed) }\end{array}$ & .47 & .20 & .45 & .16 & .14 & .13 \\
\hline & {$[.45, .49]$} & {$[.18, .22]$} & {$[.27, .62]$} & {$[.04, .28]$} & {$[.10, .19]$} & {$[.10, .16]$} \\
\hline
\end{tabular}

Legend: $\mathrm{MZ}$ - monozygotic twin pairs raised together; $\mathrm{DZ}$ - dizygotic twin pairs raised together; MZA - monozygotic twin pairs raised apart; DZ - dizygotic twin pairs raised apart; $\mathrm{MO}$ - mother-offspring; $\mathrm{FO}$ - father-offspring.

Results of the six small meta-analyses, represented in the second row of Table 2, suggest several possible conclusions. First, average correlation coefficients are statistically significant, with none of the confidence intervals including zero. Second, intraclass correlations for monozygotic twin pairs (reared together as well as those reared apart) are larger than intraclass correlations for dizygotic twin pairs. This indicates that there is a genetic effect underlying individual differences in personality. Third, intraclass correlations of twin pairs raised together are very similar to those of pairs raised apart, indicated that sharing family environment does not contribute to their similarity. Fourth, intraclass correlations for monozygotic twin pairs (reared together as well as those reared apart) are more than twice the intraclass correlations for dizygotic twin pairs. This indicates that, apart from the additive genetic effects, non-additive genetic effects also play a part in explaining the underlying individual differences in personality. Fifth, heritability estimates calculated from intraclass correlations for twin pairs reared together using Falconer's formula $\left[h^{2}=2\left(r_{\mathrm{MZ}}-r_{\mathrm{DZ}}\right)\right]$ and intraclass correlations for monozygotic twin pairs reared apart $\left(h^{2}=r_{\mathrm{MZA}}\right)$, are larger compared to familial aggregation $\left(f^{2}=2^{*} r_{\text {parent- }}\right.$ offspring) estimates (.54 and .45 vs. .26 and .28). This finding is in line with the

\footnotetext{
${ }^{2}$ Four coders were selected as the best psychology graduate students in their class. They underwent an introduction course in meta-anaysis organized by the third author, and passed the coding training before being included in the coding process.
} 
conclusion of our previous meta-analysis (Vukasović \& Bratko, 2015), which first empirically tested and confirmed that study design was a significant moderator of personality heritability, with twin studies showing higher estimates (.47) compared to family and adoption studies (.25).

\section{Findings from Molecular Genetic Studies: Which Genes Contribute to the Heritability of Personality?}

The results of the quantitative genetic studies indicate substantial genetic contribution to the individual differences in personality. However, the results of the molecular genetic studies, which aim at specific genes that contribute to this effect, are mixed and often difficult to replicate. This is in line with the empirical finding in the field that, although total genetic effect may be quite large, behavioral phenotypes are usually related to many genes which individually have a small effect on the variation of the phenotype (e.g. Davies et al., 2015; Hellard \& Steen, 2014). Similarly for personality, the molecular genetic studies indicate several genes with the small effects which contribute to the personality variance (de Moor et al., 2012; Munafo, Clark, Moore, Walton, \& Flint, 2003; Schinka, Brusch, \& Robichauw-Keene, 2004). However, the estimate of heritability from these studies is much lower than the effect size in quantitative genetic studies.

Turkheimer et al. (2014) distinguish three phases of molecular genetic studies of personality: (i) an anticipatory phase, (ii) a period of considerable empirical optimism, and (iii) an extended period of frustration. Since quantitative genetic studies of personality have consistently reported that personality is heritable, it was expected that molecular genetic studies of personality will find genetic variants associated with differences in personality traits. And in the beginning, results were very optimistic. In 1996 two articles were published simultaneously in Nature Genetics showing an association between novelty seeking measured with different personality inventories (TPQ and NEO-PI-R) and the dopamine D4 receptor gene (Benjamin et al., 1996; Ebstein et al., 1996). They were quickly followed by the study showing an association between neuroticism from NEO-PI-R and the serotonin transporter gene (Lesch et al., 1996). These reports were then followed by a series of studies resulting in both successful and unsuccessful efforts at replicating these first studies, leading to the third phase of extended frustration. A meta-analysis conducted on studies reporting data on associations between candidate genes and human personality have shown no significant associations (Munafo et al., 2003). A metaanalysis of GWAS for personality used NEO-PI-R data and information on 2.4 million SNPs from 10 independent samples constituting a total of 17375 adults, with five additional samples, with 3294 adults, as a replication sample. Two SNPs showed genome wide association with openness and one with conscientiousness, each accounting for a little more than $0.2 \%$ of the variation, but effects did not replicate on a replication sample (de Moor et al., 2012). All this led to the formulation of a missing heritability problem, dealing with the fact that, although quantitative 
genetic research showed that different phenotypes are heritable, molecular genetic research has not found single genetic variations accounting for much of that heritability. For example, height is a very heritable phenotype, and a study examining it in eight different populations gave estimations as high as 90\% (Silventoinen et al., 2003). However, GWAS trying to reliably associate the published SNPs with height, as in most cases, explained only a small proportion of the known genetic variance, around 10\% (e.g. Allen et al., 2010). Researchers believe that the problem is that many SNPs account for that known genetic variance with a very small effect. In line with that idea, Yang et al. (2010) estimated the total variance explained by the SNPs, without focusing on individual SNPs, and showed that common SNPs explain around $45 \%$ of the phenotypic variance in height. This method was also applied to personality. Vinkhuyzen et al. (2012), using genome wide SNP data from approximately 12000 unrelated individuals, estimated that common SNPs explain $6 \%$ and $12 \%$ of the phenotypic variance for neuroticism and extraversion, respectively.

Today researchers agree that personality traits are influenced by many genes, possibly thousands, of relative small effect, which means that both (i) samples that are larger than the ones used so far, even by GWAS, and (ii) more narrow and specific phenotypes, such as subtraits or facets, should be examined in the future. Another useful approach could be an investigation of gene-gene (GxG) and geneenvironment (GxE) interactions (Balestri, Calati, Serretti, \& De Ronchi, 2014).

\section{Gene-Environment Interaction Studies in Personality}

Gene-gene (GxG) and gene-environment (GxE) interactions have been mentioned as possible sources of missing heritability (Plomin, 2013). Interactions between genes, called epistatic interaction, a form of non-additive genetic effects, describe the interactions between genes that are not alleles. As mentioned earlier, differences in heritability estimates between different study designs indicate the importance of gene-gene interactions for personality. GxE interactions refer to statistical interaction between genotypes and environments, in a sense that genetic variation is expressed conditionally, as a function of environmental factors to which some, but not all, individuals are exposed (Manuck \& McCaffery, 2014). GxE interactions can be studied at the latent or at the molecular level of analysis. On a latent or biometric level focus is on the environmental moderation of a latent or inferred genetic risk, while on a molecular level focus is on the environmental moderation of the expression of the directly measured genes (Burt, 2008).

Burt (2008) summarized GxE studies in personality on both latent and molecular level of analysis. Three studies examined GxE interaction in impulsivity on a molecular level with dopamine D4 receptor gene and found an interaction with parenting quality (Sheese, Voelker, Rothbart, \& Posner, 2007), hostile childhood environment (Keltikangas-Järvinen, Räikkönen, Ekelund, \& Peltonen, 2004) and 
frequency of paternal drunkenness (Lahti et al., 2010). This line of research has led to GxE experiments, which test the differential susceptibility model. The differential susceptibility hypothesis proposes that in positive environments vulnerable children may outperform their peers, who turn out to be less susceptible not only to bad environments, but also to optimal environments (Bakermans-Kranenburg \& Van IJzendoorn, 2007). Recent meta-analysis of randomized GxE experiments has shown support for the differential susceptibility model with dopamine-related genes emerging as susceptibility markers. The effects of experimental manipulation of the environment for the better were much stronger in the susceptible genotypes than in the non-susceptible genotypes (Bakermans-Kranenburg \& Van IJzendoorn, 2015).

Studies examining GxE interaction on a latent level have yielded mixed results. In a Burt (2008) review one study found significant GxE interaction for impulsivity (Boomsma, De Geus, Van Baal, \& Koopmans, 1999) and one has not (Krueger, South, Johnson, \& Iacono, 2008), while for neuroticism two have found significant GxE interaction (Jang, Dick, Wolf, Livesley, \& Paris, 2005; Krueger et al., 2008), and one has not (Kendler, Aggen, Jacobson, \& Neale, 2003). Additionally, LemeryChalfant, Kao, Swann, and Goldsmith (2013) have also found significant GxE interaction for neuroticism. Finally, two studies have found significant GxE interaction for extraversion (Krueger et al., 2008; Lemery-Chalfant et al., 2013).

Like candidate gene studies generally, $\mathrm{G} \times \mathrm{E}$ findings have been challenged for limited replication and vulnerability to publication bias (Manuck \& McCaffery, 2014). Recently, Windle and Mrug (2015) suggested that what is needed as a complementary approach to GWAS are hypothesis-driven and biologically informed research for GxE interactions. Their study used prior research studies and developmental an evolutionary theory to guide hypothesis testing of GxE relationships, and their findings supported the hypothesized interaction.

\section{Some Concluding Thoughts}

Review and the meta-analysis of the behavioral genetic studies of personality presented here support the genetic hypothesis without any doubt. Individual differences in personality traits are heritable. On the other hand, how important is that? Is the precise heritability estimate the most important goal of the behavioral genetic studies of personality? One possible position is that, once the heritability is established, the magnitude of genetic influence is not so important. Obviously, as Johnson, Penke, and Spinath (2011) argue, although the genetic influence on behavior is ubiquitous, the size of heritability estimates are related not only to the biological reality, but also to the non-biological issues like test-retest reliability of the measures, the quantity of the aggregation of a heritable behaviors within the scales, or to the frequency of the response which is reflected in variability of the analyzed phenotype (p. 256; see also Riemann, Kandler, \& Bleidorn, 2011). Heritability is essentially the effect size of the genetic influence and it is sensitive to all 
psychometric factors which may bias the estimate of the effect size in any correlational study. However, since there is some "exact number" or "true effect size", which reflects the heritability in a population, we are trying to figure it out with our imperfect methods, personality models and measures. Although the heritability estimate may not be the ultimate goal of behavioral genetics, the quantitative genetic analysis of various behavioral phenotypes yielded surprisingly consistent results. Polderman et al. (2015) reported results of the meta-analysis of virtually all published twin studies of complex traits. They analyzed 17804 traits from 2748 publications, and across all traits the heritability estimate was .49 , which is exactly the same estimate of heritability as is the estimate from the twin studies of personality (Vukasović \& Bratko, 2015). Obviously, we have very consistent results of the studies within the same methods or study designs. However, behavior genetic studies of personality conducted with different methods yielded inconsistent results, which needs to be theoretically explained. According to our view, two phenomena are particularly relevant. First, the results of twin studies are inconsistent with the results of the family and adoption studies in a way that twin studies consistently result in larger genetic effect sizes. Although this may happen for various reasons, the possibility of non-additive genetic effect or gene-gene interactions is theoretically the most relevant explanation. However, interaction is very difficult to prove in a situation where the main effect of individual gene is extremely small. Second, results of the quantitative genetic studies and molecular genetic studies are also inconsistent. Overall, the genetic effect estimated from the quantitative genetics studies substantially exceeds the variance explained by the molecular genetic findings. This 'missing heritability' is one of the central problems in the field and it is on the agenda for future research. It is important to notice that same phenomena exist for the environmental effect size as well. The quantitative genetic estimates of environmental effect by far exceed the effect sizes that are typically estimated in the studies of measured environment. Thus, we may introduce the term 'missing environmentality'. Typical effect sizes in personality psychology are small, as well as in other psychological domains (Roberts, Kuncel, Shiner, Caspi, \& Goldberg, 2007), and it seems that quantitative genetics utilizes the principle of aggregation.

And last but not least, behavioral genetic studies are completely in line with other studies in behavioural sciences - they are typically conducted in Western, Educated, Industrialized, Rich, and Democratic societies, named WIERD societies by Henrich, Heine, \& Norenzayan (2010), because they are among the least representative populations for the human species. The existing studies of personality heritability cover well the populations of Western Europe, North America, and Australia, but little is known about the populations of Asia, South America or Africa (Vukasović \& Bratko, 2015). Since these populations may differ on some potentially relevant dimensions (e.g. individualism-collectivism), the future cross-cultural comparison of the personality heritability would be welcome. Since we can expect that the relevance of the trait concept for the explanation of the behavioral individual differences could be smaller in collectivistic cultures (Church, 2009), the plausible 
hypothesis would be that heritability of personality traits would be lower in these cultures. However, at this point in time, there is not enough relevant empirical studies to test this hypothesis.

\section{References}

References marked with an asterisk indicate studies included in the meta-analysis.

*Ahern, F.M., Johnson, R.C., Wilson, J.R., McClearn, G.E., \& Vandenberg, S.G. (1982). Family resemblances in personality. Behavior Genetics, 12, 261-280. http://dx.doi.org/10.1007/BF01067847

Allen, H.L., Estrada, K., Lettre, G., Berndt, S.I., Weedon, M.N., Rivadeneira, F., ... Ferreira, T. (2010). Hundreds of variants clustered in genomic loci and biological pathways affect human height. Nature, 467(7317), 832-838.

*Baker, L.A., \& Daniels, D. (1990). Nonshared environmental influences and personality differences in adult twins. Journal of Personality and Social Psychology, 58, 103-110. http://dx.doi.org/10.1037/0022-3514.58.1.103

Bakermans-Kranenburg, M.J., \& Van IJzendoorn, M.H. (2007). Genetic vulnerability or differential susceptibility in child development: The case of attachment. Journal of Child Psychology and Psychiatry, 48, 14.

Bakermans-Kranenburg, M.J., \& Van IJzendoorn, M.H. (2015). The hidden efficacy of interventions: Gene× environment experiments from a differential susceptibility perspective. Annual Review of Psychology, 66, 381-409.

Balestri, M., Calati, R., Serretti, A., \& De Ronchi, D. (2014). Genetic modulation of personality traits: A systematic review of the literature. International Clinical Psychopharmacology, 29(1), 1-15.

Benjamin, J., Li, L., Patterson, C., Greenberg, B.D., Murphy, D.L., \& Hamer, D.H. (1996). Population and familial association between the D4 dopamine receptor gene and measures of Novelty Seeking. Nature Genetics, 12, 81-84.

Boomsma, D.I., De Geus, E.J., Van Baal, G.C.M., \& Koopmans, J.R. (1999). A religious upbringing reduces the influence of genetic factors on disinhibition: Evidence for interaction between genotype and environment on personality. Twin Research, 2(02), 115-125.

*Bratko, D., \& Butković, A. (2007). Stability of genetic and environmental effects from adolescence to young adulthood: Results of Croatian longitudinal twin study of personality. Twin Research and Human Genetics, 10, 151-157. http://dx.doi.org/ 10.1375/twin.10.1.151

*Bratko, D., \& Marušić, I. (1997). Family study of the Big Five personality dimensions. Personality and Individual Differences, 23, 365-369. http://dx.doi.org/10.1016/S01918869(97)00081-0 
Burt, S.A. (2008). Gene-environment interactions and their impact on the development of personality traits. Psychiatry, 7(12), 507-510.

Cervone, D., \& Pervin, L.A. (2016). Personality: Theory and research (13th Ed.). New York: Wiley.

Chiao, J.Y., \& Blizinsky, K.D. (2010). Culture-gene coevolution of individualismcollectivism and the serotonin transporter gene. Proceedings of the Royal Society B: Biological Sciences, 277, 529-537.

Church, A.T. (2009). Prospects for an integrated trait and cultural psychology. European Journal of Personality, 23(3), 153-182.

Costa, P.T., Jr., \& McCrae, R.R. (1992). Revised NEO Personality Inventory (NEO-PI-R) and NEO Five-Factor Inventory (NEO-FFI). Professional Manual. Psychological Assessment Resources, Inc.

Costa, P.T., Jr., \& McCrae, R.R. (1992). NEO PI-R. Professional manual. Odessa, FL: Psychological Assessment Resources, Inc.

*Coppen, A., Cowie, V., \& Slater, E. (1965). Familial aspects of "neuroticism" and "extraversion." The British Journal of Psychiatry, 111, 70-83. http://dx.doi.org/10.1192/ bjp. 111.470 .70

Davies, G., Armstrong, N., Bis, J.C., Bressler, J., Chouraki, V., Giddaluru, S., ... Van Der Lee, S.J. (2015). Genetic contributions to variation in general cognitive function: A metaanalysis of genome-wide association studies in the CHARGE consortium ( $\mathrm{N}=53$ 949). Molecular Psychiatry, 20(2), 183-192.

de Moor, M.H.M., Costa, P.T., Terracciano, A., Krueger, R.F., de Geus E.J.C., Toshiko, T., ... Boomsma, D.I. (2012). Meta-analysis of genome-wide association studies for personality. Molecular Psychiatry, 17, 337-349. doi:10.1038/mp.2010.128

*Eaves, L.J., Heath, A., Martin, N., Maes, H., Neale, M., Kendler, K., ... Corey, L. (1999). Comparing the biological and cultural inheritance of personality and social attitudes in the Virginia 30,000 study of twins and their relatives. Twin Research, 2, 62-80. http://dx.doi.org/10.1375/136905299320565933

*Eaves, L.J., Heath, A.C., Neale, M.C., Hewitt, J.K., \& Martin, N.G. (1998). Sex differences and non-additivity in the effects of genes on personality. Twin Research, 1, 131-137.

Ebstein, R.P., Novick, O., Umansky, R., Priel, B., Osher, Y., Blaine, D., Bennett, E.R., Nemanov, L., Katz, M., \& Belmaker, R.H. (1996). Dopamine D4 receptor (D4DR) exon III polymorphism associated with the human personality trait of Novelty Seeking. Nature Genetics, 12, 78-80.

Eysenck, H.J. (1967). The biological basis of personality. Springfiled, IL: Thomas.

Eysenck, H.J. (1990). Biological dimensions of personality. In L.A. Pervin (Ed.), Handbook of personality: Theory and research (pp. 244-276). New York: Guilford.

*Finkel, D., \& McGue, M. (1997). Sex differences and nonadditivity in heritability of the Multidimensional Personality Questionnaire scales. Journal of Personality and Social Psychology, 72, 929-938. http://dx.doi.org/10.1037/0022-3514.72.4.929 
*Floderus-Myrhed, B., Pedersen, N., \& Rasmuson, I. (1980). Assessment of heritability for personality, based on a short-form of the Eysenck Personality Inventory: A study of 12,898 twin pairs. Behavior Genetics, 10, 153-162. http://dx.doi.org/10.1007/ BF01066265

*Gillespie, N.A., Evans, D.E., Wright, M.M., \& Martin, N.G. (2004). Genetic simplex modeling of Eysenck's dimensions of personality in a sample of young Australian twins. Twin Research, 7, 637-648. http://dx.doi.org/10.1375/1369052042663814

Goldberg, L.R. (1990). An alternative "description of personality": The Big-Five factor structure. Journal of Personality and Social Psychology, 59(6), 1216-1229. doi:10.1037/0022-3514.59.6.1216

Harris, J.R. (1998). The nurture assumption: Why children turn out the way they do. New York: Free Press.

Hayes, A.F., \& Krippendorff, K. (2007). Answering the call for a standard reliability measure for coding data. Communication Methods and Measures, 1(1), 77-89. doi:10.1080/ 19312450709336664

Hellard, S., \& Steen, V.M. (2014). Genetic architecture of cognitive traits. Scandinavian Journal of Psychology, 55(3), 255-262.

Henrich, J., Heine, S.J., \& Norenzayan, A. (2010). The weirdest people in the world? Behavioral and Brain Sciences, 33(2-3), 61-83. doi:10.1017/S0140525X0999152X

*Hur, Y.-M. (2007). Evidence for nonadditive genetic effects on Eysenck personality scales in South Korean twins. Twin Research and Human Genetics, 10, 373-378. http://dx.doi.org/10.1375/twin.10.2.373

*Insel, P.M. (1974). Maternal effects in personality. Behavior Genetics, 4, 133-143.

Jang, K.L., Dick, D.M., Wolf, H., Livesley, W.J., \& Paris, J. (2005). Psychosocial adversity and emotional instability: An application of gene-environment interaction models. European Journal of Personality, 19(4), 359-372.

*Jang, K.L., Livesley, W.J., \& Vernon, P.A. (1996). Heritability of the Big Five personality dimensions and their facets: A twin study. Journal of Personality, 64, 577-592. http://dx.doi.org/10.1111/j.1467-6494.1996.tb00522.x

*Johnson, W., McGue, M., \& Krueger, R.F. (2005). Personality stability in late adulthood: A behavioral genetic analysis. Journal of Personality, 73(2), 523-552.

Johnson, W., Penke, L., \& Spinath, F.M. (2011). Heritability in the era of molecular genetics: Some thoughts for understanding genetic influences on behavioural traits. European Journal of Personality, 25(4), 254-266.

Kandler, C., Riemann, R., Spinath, F.M., \& Angleitner, A. (2010). Sources of variance in personality facets: A multiple-rater twin study of self-peer, peer-peer, and self-self (dis)agreement. Journal of Personality, 78(5), 1565-1594. doi:10.1111/j.1467-6494. 2010.00661.x 
Keller, M.C., Coventry, W.L., Heath, A.C., \& Martin, N.G. (2005). Widespread evidence for non-additive genetic variation in Cloninger's and Eysenck's personality dimensions using a twin plus sibling design. Behavior Genetics, 35(6), 707-721. doi:10.1007/ s10519-005-6041-7

Keltikangas-Järvinen, L., Räikkönen, K., Ekelund, J., \& Peltonen, L. (2004). Nature and nurture in novelty seeking. Molecular Psychiatry, 9(3), 308-311.

Kendler, K.S., Aggen, S.H., Jacobson, K.C., \& Neale, M.C. (2003). Does the level of family dysfunction moderate the impact of genetic factors on the personality trait of neuroticism?. Psychological Medicine, 33(05), 817-825.

*Kendler, K.S., Myers, J., Potter, J., \& Opalesky, J. (2009). A web-based study of personality, psychopathology and substance use in twin, other relative and relationship pairs. Twin Research and Human Genetics, 12, 137-141. http://dx.doi.org/10.1375/twin.12.2.137

Krueger, R.F., \& Johnson, W. (2008). Behavioral genetics and personality: A new look at the integration of nature and nurture. In O.P. John, R.W. Robins, \& L.A. Pervin (Eds.), Handbook personality: Theory and research (3rd ed., 287-310). New York-London: The Guilford Press.

Krueger, R.F., South, S., Johnson, W., \& Iacono, W. (2008). The heritability of personality is not always 50\%: Gene-environment interactions and correlations between personality and parenting. Journal of Personality, 76(6), 1485-1522.

Lahti, J., Räikkönen, K., Ekelund, J., Peltonen, L., Raitakari, O.T., \& Keltikangas-Järvinen, L. (2010). Novelty seeking: Interaction between parental alcohol use and dopamine D4 receptor gene exon III polymorphism over 17 years. Focus, 8(2), 294-300.

Larsen, R.J., \& Buss, D. (2014). Personality psychology: Domains of knowledge about human nature. Fifth edition. Boston: McGraw Hill.

Lemery-Chalfant, K., Kao, K., Swann, G., \& Goldsmith, H.H. (2013). Childhood temperament: Passive gene-environment correlation, gene-environment interaction, and the hidden importance of the family environment. Development and Psychopathology, 25(01), 51-63.

*Lensvelt-Mulders, G., \& Hettema, J. (2001). Analysis of genetic influences on the consistency and variability of the Big Five across different stressful situations. European Journal of Personality, 15, 355-371. http://dx.doi.org/10.1002/per.414

Lesch, K.P., Bengel, D., Heils, A., Sabol, S.Z., Greenberg, B.D., Petri, S., Benjamin, J., Mueller, C.R., Hamer, D.H., \& Murphy, D.L. (1996). Association of anxiety-related traits with a polymorphism in the serotonin transporter gene regulatory region. Science, 274, 1527-31.

Loehlin, J.C. (1978). Are CPI scales differently heritable: How good is the evidence? Behavior Genetics, 8(4), 381-382. doi:10.1007/BF01067402

Loehlin, J.C. (1982). Are personality traits differentially heritable? Behavior Genetics, 12(4), 417-428. doi: 10.1007/BF01065633 
Loehlin, J.C. (2012). The differential heritability of personality item clusters. Behavior Genetics, 42(3), 500-507. doi: 10.1007/s10519-011-9515-9

*Loehlin, J.C., \& Martin, N. (2001). Age changes in personality traits and their heritabilities during the adult years: Evidence from Australian twin registry samples. Personality and Individual Differences, 30, 1147-1160. http://dx.doi.org/10.1016/S0191-8869(00) 00099-4

*Loehlin, J.C., McCrae, R.R., Costa, P.T., Jr., \& John, O.P. (1998). Heritabilities of common and measure-specific components of the Big Five personality factors. Journal of Research in Personality, 32, 431-453. http://dx.doi.org/10.1006/jrpe.1998.2225

*Losoya, S.H., Callor, S., Rowe, D.C., \& Goldsmith, H.H. (1997). Origins of familial similarity in parenting: A study of twins and adoptive siblings. Developmental Psychology, 33, 1012-1023. http://dx.doi.org/10.1037/0012-1649.33.6.1012

Manuck, S.B., \& McCaffery, J.M. (2014). Gene-environment interaction. Annual Review of Psychology, 65, 41-70.

*Martin, N., Goodwin, G., Fairburn, C., Wilson, R., Allison, D., Cardon, L.R., \& Flint, J. (2000). A population-based study of personality in 34,000 sib-pairs. Twin Research, 3, 310-315.

Munafo, M.R., Clark, T.G., Moore, L.R., Walton, R., \& Flint, J. (2003). Genetic polymorphisms and personality in healthy adults: A systematic review and metaanalysis. Molecular Psychiatry, 8, 471-484. doi: 10.1038/sj.mp.4001326

Nelson, R.M., Pettersson, M.E., \& Carlborg, Ö. (2013). A century after Fisher: Time for a new paradigm in quantitative genetics. Trends in Genetics, 29(12), 669-676.

*Pedersen, N.L., Plomin, R., McClearn, G.E., \& Friberg, L. (1988). Neuroticism, extraversion, and related traits in adult twins reared apart and reared together. Journal of Personality and Social Psychology, 55, 950-957. http://dx.doi.org/10.1037/00223514.55.6.950

Plomin, R. (2013). Child development and molecular genetics: 14 years later. Child Development, 84(1), 104-120.

Plomin, R., \& Daniels, D. (1987). Why are children in the same family so different from one another? Behavioral and Brain Sciences, 10, 1-60.

Plomin, R., DeFries, J.C., McClearn, G.E., \& McGuffin, P. (2008). Behavioral genetics (5th ed.). New York: Worth Publishers.

Polderman, T.J., Benyamin, B., De Leeuw, C.A., Sullivan, P.F., Van Bochoven, A., Visscher, P.M., \& Posthuma, D. (2015). Meta-analysis of the heritability of human traits based on fifty years of twin studies. Nature Genetics, 47(7), 702-709.

Posthuma, D., \& Boomsma, D. (2000). A note on the statistical power in extended twin designs. Behavior Genetics, 30(2), 147-158. doi: 10.1023/A:1001959306025

Reber, A.S. (1995). The Penguin dictionary of psychology. Penguin Press. 
*Riemann, R., Angleitner, A., \& Strelau, J. (1997). Genetic and environmental influences on personality: A study of twins reared together using the self- and peer report NEO-FFI scales. Journal of Personality, 65, 449-475. http://dx.doi.org/10.1111/j.14676494.1997.tb00324.x

Riemann, R., Kandler, C., \& Bleidorn, W. (2011). Size matters! Heritability is not dichotomous. European Journal of Personality, 25(4).

Roberts, B.W., Kuncel, N.R., Shiner, R., Caspi, A., \& Goldberg, L.R. (2007). The power of personality: The comparative validity of personality traits, socioeconomic status, and cognitive ability for predicting important life outcomes. Perspectives on Psychological Science, 2(4), 313-345.

*Rose, R.J., Koskenvuo, M., Kaprio, J., Sarna, S., \& Langinvainio, H. (1988). Shared genes, shared experiences, and similarity of personality: Data from 14,288 adult Finnish cotwins. Journal of Personality and Social Psychology, 54, 161-171. http://dx.doi.org/ 10.1037/0022-3514.54.1.161

*Saudino, K.J., Gagne, J.R., Grant, J., Ibatoulina, A., Marytuina, T., Ravich-Scherbo, I., \& Whitfield, K. (1999). Genetic and environmental influences on personality in adult Russian twins. International Journal of Behavioral Development, 23(2), 375-389.

*Scarr, S., Webber, P.L., Weinberg, R.A., \& Wittig, M.A. (1981). Personality resemblance among adolescents and their parents in biologically related and adoptive families. Journal of Personality and Social Psychology, 40, 885-898. http://dx.doi.org/ 10.1037/0022-3514.40.5

Schinka, J.A., Busch, R.M., \& Robichaux-Keene, N. (2004). A meta-analysis of the association between the serotonin transporter gene polymorphism (5-HTTLPR) and trait anxiety. Molecular Psychiatry, 9, 197-202. doi: 10.1038/sj.mp.4001405

Sheese, B.E., Voelker, P.M., Rothbart, M.K., \& Posner, M.I. (2007). Parenting quality interacts with genetic variation in dopamine receptor D4 to influence temperament in early childhood. Development and Psychopathology, 19(04), 1039-1046.

*Shields, J. (1958). Twins brought up apart. The Eugenics Review, 50, 115-123.

Silventoinen, K., Sammalisto, S., Perola, M., Boomsma, D.I., Cornes, B.K., Davis, C., Dunkel, L., de Lange, M., Harris, J.R., Hjelmborg, J.V.B., Luciano, M., Martin, N.G., Mortensen, J., Nistico, L., Pedersen, M.L., Skytthe, A., Spector, T.D., Stazi, M.A., Willemsen, G., \& Kaprio, J. (2003). Heritability of adult body height: A comparative study of twin cohorts in eight countries. Twin Research, 6(05), 399-408.

*South, S.C., Krueger, R.F., Johnson, W., \& Iacono, W.G. (2008). Adole on relationships with parents. Journal of Personality and Social Psychology, 94, 899-912. http://dx.doi.org/10.1037/0022-3514.94.5.899

*Tambs, K., Sundet, J.M., Eaves, L., Solaas, M.H., \& Berg, K. (1991). Pedigree analysis of Eysenck Personality Questionnaire (EPQ) scores in monozygotic (MZ) twin families. Behavior Genetics, 21, 369-382. http://dx.doi.org/10.1007/BF01065973

Tellegen, A. (1982). Brief manual for the multidimensional personality questionnaire. Unpublished manuscript, University of Minnesota. 
*Tellegen, A., Lykken, D.T., Bouchard, T.J., Jr., Wilcox, K.J., Segal, N.L., \& Rich, S. (1988). Personality similarity in twins reared apart and together. Journal of Personality and Social Psychology, 54, 1031-1039. http://dx.doi.org/10.1037/0022-3514.54.6.1031

Turkheimer, E. (2000). Three laws of behavior genetics and what they mean. Current Directions in Psychological Science, 9, 160-164. doi:10.1111/1467-8721.00084

Turkheimer, E., \& Gottesman, I.I. (1991). Is H2=0 a null hypothesis anymore? Behavioral and Brain Sciences, 14, 410-411.

Turkheimer, E., Pettersson, E., \& Horn, E.E. (2014). A phenotypic null hypothesis for the genetics of personality. Annual Review of Psychology, 65, 515-540. http://dx.doi.org/10.1146/annurev-psych-113011-143752

Turkheimer, E., \& Waldron, M. (2000). Nonshared environment: A theoretical, methodological, and quantitative review. Psychological Bulletin, 126, 78-108. doi:10.1037/0033-2909.126.1.78

*Valera, E.M., \& Berenbaum, H. (2001). A twin study of alexithymia. Psychotherapy and Psychosomatics, 70, 239-246. http://dx.doi.org/10.1159/000056261

*Vernon, P.A., Martin, R.A., Schermer, J.A., \& Mackie, A. (2008). A behavioral genetic investigation of humor styles and their correlations with the Big-5 personality dimensions. Personality and Individual Differences, 44, 1116-1125. http://dx.doi.org/ 10.1016/j.paid.2007.11.003

Vinkhuyzen, A.A., Pedersen, N.L., Yang, J., Lee, S.H., Magnusson, P.K., Iacono, W.G., ... Payton, A. (2012). Common SNPs explain some of the variation in the personality dimensions of neuroticism and extraversion. Translational Psychiatry, 2(4), e102.

*Vukasović, T., Bratko, D., \& Butković, A. (2009). From specific reactions to aggregated dimensions of personality: Familial aggregation estimate in the function of construct width. Contemporary Psychology, 12, 323-339.

Vukasović, T., \& Bratko, D. (2015). Heritability of personality: A meta-analysis of behavior genetic studies. Psychological Bulletin, 141, 769-785. http://dx.doi.org/10.1037/ bul0000017

*Weiss, A., Bates, T.C., \& Luciano, M. (2008). Happiness is a personal-(ity) thing: The genetics of personality and well-being in a representative sample. Psychological Science, 19, 205-210. http://dx.doi.org/10.1111/j.1467-9280.2008.02068.x

Windle, M., \& Mrug, S. (2015). Hypothesis-driven research for $\mathrm{G} \times \mathrm{E}$ interactions: The relationship between oxytocin, parental divorce during adolescence, and depression in young adulthood. Frontiers in Psychology, 6, 1322.

Yang, J., Benyamin, B., McEvoy, B.P., Gordon, S., Henders, A.K., Nyholt, D.R., ... Goddard, M.E. (2010). Common SNPs explain a large proportion of the heritability for human height. Nature Genetics, 42(7), 565-569. 


\section{Heredabilidad de la personalidad}

\section{Resumen}

El objetivo de este estudio es simplificar la cuestión del concepto de la heredabilidad, ofrecer una introducción a la teoría y métodos de la genética conductual y dar una reseña del conocimiento actual sobre la heredabilidad de la personalidad y el enfoque genético cuantitativo y molecular para calcular heredabilidad. Luego se resumen los resultados sobre la heredabilidad de la personalidad. Además, reanalizamos todos los estudios genéticos conductuales disponibles publicados antes de 2010, que formaron parte del metaanálisis de Vukasović y Bratko (2015), para estimar las correlaciones entre diferentes miembros de familia: 1) gemelos criados juntos, 2) gemelos criados separados, 3) mellizos criados juntos, 4) mellizos criados separados, 5) madres y descendencia, 6) padres y descendencia. Cálculos sobre la semejanza familiar para la personalidad fueron .54 para la correlación intraclase para gemelos criados juntos, .45 para gemelos criados aparte y .26 y .28 para la agregación familiar. Este hallazgo corresponde a la conclusión de los metaanálisis previos, los cuales mostraron que el diseño de estudio es un moderador significante de la heredabilidad de la personalidad, y que los estudios de gemelos muestran cálculos más altos comparados con los estudios de familia y adopción. En continuación se resumen los hallazgos de los estudios de genética molecular sobre la personalidad y de la interacción entre genotipo y ambiente. Al final se ofrecen sugerencias para futuros estudios.

Palabras claves: heredabilidad, personalidad, genética conductual, metaanálisis

Received: February 17, 2017 